\title{
PENGARUH PENDEKATAN MATEMATIKA REALISTIK (PMR) TERHADAP KEMAMPUAN PEMECAHAN MASALAH MATEMATIKA SISWA KELAS X SMA NEGERI 2 BINJAI TAHUN PELAJARAN 2018/2019
}

\author{
Desmi Primayani ${ }^{1}$, Mardiati $^{2}$
}

\begin{abstract}
ABSTRAK
Penelitian ini bertujuan untuk mengetahui pengaruh pendekatan matematika realistik (PMR) terhadap kemampuan pemecahan masalah matematika siswa. Populasi penelitian ini adalah siswa kelas X SMP Negeri 2 Binjai tahun pelajaran 2018/2019 yang berjumlah 272 orang. Secara acak, dipilih dua kelas sebagai subyek penelitian. Kelas eksperimen diberi pembelajaran pendekatan matematika realistik dengan jumlah 33 orang dan kelas kontrol diberi pembelajaran konvensional yang berjumlah 35 orang. Instrumen yang digunakan terdiri dari: tes kemampuan pemecahan masalah. Instrumen tersebut dinyatakan telah memenuhi syarat validitas serta koefisien reliabilitas untuk kemampuan pemecahan masalah matematika. Hasil utama dari penelitian ini adalah : secara keseluruhan siswa yang menggunakan pendekatan matematika realistik secara signifikan rata-rata pengaruh kemampuan pemecahan masalah matematikanya lebih baik daripada rata-rata pengaruh kemampuan pemecahan masalah matematika siswa yang menggunakan pembelajaran konvensional. Berdasarkan uji regresi linear sederhana diperoleh $r_{\text {tabel }}=0,344$ sementara berdasarkan perhitungan yang telah dilakukan diperoleh $\mathrm{r}_{\text {hitung }}=0,61$. Dari perhitungan terlihat bahwa $r_{\text {hitung }}>r_{\text {tabel }}(0,61>0,344)$ maka $\mathrm{H}_{0}$ ditolak dan $\mathrm{H}_{\mathrm{a}}$ diterima, dengan demikian dapat disimpulkan bahwa" Terdapat pengaruh pendekatan matematika realistik (PMR) terhadap kemampuan pemecahan masalah matematika siswa kelas X SMA Negeri 2 Binjai tahun pelajaran 2018/2019.
\end{abstract}

Kata Kunci : Pendekatan Matematika Realistik (PMR), Kemampuan Pemecahan Masalah Matematika.

\footnotetext{
${ }^{1}$ Mahasiswa STKIP Budidaya Binjai

${ }^{2}$ Dosen STKIP Budidaya Binjai
} 


\begin{abstract}
This study aims to determine the effect of realistic mathematical approaches (PMR) on students' mathematical problem solving abilities. The population of this study were students of class X SMP 2 Binjai in the 2018/2019 school year totaling 272 people. Randomly, two classes were chosen as research subjects. The experimental class was given a realistic mathematical approach with a total of 33 people and the control class was given conventional learning totaling 35 people. The instrument used consists of: test problem solving abilities. The instrument was declared to have fulfilled the validity requirements and reliability coefficient for mathematical problem solving abilities. The main results of this study are: overall students who use realistic mathematical approaches significantly average the influence of mathematical problem solving abilities better than the average influence of students' mathematical problem solving abilities using conventional learning. Based on the simple linear regression test obtained rtable $=0.344$ while based on the calculations that have been carried out obtained $r$ count $=0.61$. From the calculation, it can be seen that $r$ count $>r$ table $(0.61>0.344)$, then $\mathrm{HO}$ is rejected and Ha is accepted, thus it can be concluded that "There is an influence of realistic mathematical approach (PMR) on mathematical problem solving ability of class X Binjai 2 Public High School 2018/2019.
\end{abstract}

Keywords: Realistic Mathematics Approach (PMR), Mathematical Problem Solving Ability.

\section{PENDAHULUAN}

Pendidikan memiliki peranan yang sangat penting dalam kecakapan hidup manusia. Demikian juga pendidikan dapat mempengaruhi perkembangan sumber daya manusia (SDM) dalam seluruh aspek kepribadian dan kehidupannya. Proses belajar mengajar juga memerlukan variasi guna meningkatkan mutu pendidikan. Variasi dalam proses belajar mengajar ditunjukkan oleh seorang guru dengan adanya perubahan dalam gaya mengajar, variasi media yang digunakan dan adanya perubahan dalam pola interaksi antara guru dengan siswa, siswa dengan guru dan siswa dengan siswa. Proses belajar mengajar tersebut meliputi beberapa mata pelajaran yang penting pada umumnya termasuk matematika.

Istimewanya matematika adalah salah satu mata pelajaran yang diajarkan disemua jenjang pendidikan dari sekolah dasar sampai perguruan tinggi. Hal tersebut menuntut matematika sebagai ratu ilmu pengetahuan memegang peranan penting. Matematika merupakan mata pelajaran yang penting. Matematika juga merupakan salah satu penguasaan mendasar yang sangat dibutuhkan dalam perkembangan pendidikan. Seperti yang diungkapkan oleh Hujodo bahwa: "Matematika adalah suatu alat mengembangkan cara berfikir.
Karena itu matematika diperlukan untuk kehidupan sehari-hari maupun dalam menghadapi kemajuan IPTEK sehingga matematika perlu dibekalkan kepada setiap peserta didik sejak SD, bahkan sejak TK”.

Disamping itu matematika juga merupakan ilmu yang universal yang mendasari perkembangan ilmu dan teknologi modern. Sehingga jelaslah bahwa matematika mampu memajukan daya pikir manusia dan memungkinkan siapapun yang mempelajarinya terampil untuk berpikir rasional. Oleh karenanya, sangat pantas bila matematika dijadikan sebagai salah satu mata pelajaran yang diajarkan mulai dari tingkat dasar, menengah, sampai perguruan tinggi.

Namun pada kenyataannya, prestasi belajar matematika khususnya masih sangat mengecewakan dibandingkan dengan pelajaran yang lain. Kualitas pendidikan di Indonesia yang masih jauh lebih rendah dari negaranegara lain, hal ini dikuatkan hasil penilain internasional tentang prestasi siswa. "Survei Trends International Mathematics and Science Study (TIMSS) pada tahun 2015 menempatkan Indonesia pada perolehan rerata skor Matematika 397 poin, berada pada rangking 45 dari 50 negara. Hasil TIMSS Indonesia yang rendah tersebut tentunya disebabkan oleh banyak faktor. Salah satu faktor penyebabnya 
antara lain siswa di Indonesia pada umumnya kurang terlatih dalam menyelesaikan soal-soal karakteristik seperti soal-soal yang menuntut untuk mengembangkan kemampuan pemecahan masalah.

Permasalahan dalam pembelajaran matematika adalah bagaimana caranya kita menerapkan atau menyampaikan materi pelajaran agar siswa dapat memahami dan mengerti. Informasi dari SMA Negeri 2 Binjai, berkaitan dengan pembelajaran matematika di kelas X terungkap berbagai masalah. Salah satu permasalahan strategis yang dialami siswa sesuai dengan observasi pendahuluan yang peneliti lakukan adalah kurangnya kemampuan dalam pemecahan masalah matematika.

Hasil dari observasi tersebut adalah banyak siswa yang mengalami kesulitan belajar matematika terutama dalam menyelesakan soal cerita. Karena siswa masih sulit untuk memahami masalah, merencanakan pemecahan masalah dan melaksanaakan penyelesaian masalah. Hal ini menunjukkan bahwa kemampuan pemecahan masalah matematika siswa masih rendah padahal pemecahan masalah mengharapkan siswa mampu memahami apa yang menjadi akar masalah, menyusun rencana yang tepat untuk masalah tersebut dan melaksanakannya serta memiliki kemampuan untuk memeriksa kembali hasil yang diperoleh. Dan salah satu pendekatan yang tepat untuk mengembangkan kemampuan pemecahan masalah matematika siswa adalah pendekatan matematika realistik (PMR).

Pendekatan matematika realistik (PMR), dimana dalam Pendekatan ini siswa dituntut untuk dapat menerapkan pembelajaran dalam kehidupan sehari-hari. Selanjutnya siswa dapat menyelesaikan masalah tersebut dengan langsung menggunakan konsep yang telah dimilikinya atau siswa tersebut menyelesaikan masalah dengan mengubah ke dalam model matematika lalu menggunakan konsep yang telah dimilikinya untuk menyelesaikan masalah. Pada pendekatan ini, dalam memecahkan masalah siswa dituntut bekerja sama dalam suatu kelompok, siswa berinteraksi memberikan ide-ide yang membangun. Sehingga dalam kegiatan pembelajaran didalam kelas akan melibatkan seluruh siswa.

Materi yang dipilih peneliti adalah sistem persamaan linear tiga variabel yang materinya banyak berkaitan dengan kehidupan nyata. Dalam materi ini, banyak cara yang dapat digunakan siswa untuk diaplikasikan dalam memecahkan berbagai masalah dalam kehidupan sehari-hari. Oleh sebab itu, dalam hal mengajarkan sistem persamaan linear tiga variabel, guru harus mampu memilih dan menggunakan metode yang tepat, sehingga kemampuan siswa dalam memecahkan masalah bentuk aljabar dapat diatasi.

Berdasarkan uraian diatas, perlu diadakan penelitian untuk mengetahui pengaruh pendekatan matematika realistik (PMR) terhadap kemampuan pemecahan masalah matematika siswa kelas X SMA Negeri 2 Binjai tahun pelajaran 2018/2019. Adapun yang menjadi rumusan masalah dalam penelitian ini adalah : apakah terdapat pengaruh pendekatan matematika realistik (PMR) terhadap kemampuan pemecahan masalah matematika siswa kelas X SMA Negeri 2 Binjai tahun pelajaran 2018/2019?. Tujuan penelitian ini adalah : untuk melihat pengaruh pendekatan matematika realistik (PMR) terhadap kemampuan pemecahan masalah matematika siswa kelas X SMA Negeri 2 Binjai tahun pelajaran 2018/2019

\section{METODE PENELITIAN}

Penelitian ini merupakan penelitian quasi eksperimen (eksperimen semu) yang dilakukan di SMA Negeri 2 Binjai Tahun Pelajaran 2018/2019. Penelitian ini dilakukan di SMA Negeri 2 Binjai. Populasi dari penelitian ini adalah seluruh kelas X SMA Negeri 2 Binjai. Sampel penelitian ini adalah kelas X PMS-4 sebagai kelas eksperimen dengan jumlah siswa 33 dan kelas X PMS-5 sebagai kelas kontrol dengan jumlah siswa 35 . Teknik pengambilan sampel yang digunakan adalah Simple Random Sampling.

Desain penelitian yang digunakan adalah Control Group Pre-test-Post-test yang merupakan bentuk desain penelitian quasi eksperimen (eksperimen semu).

\begin{tabular}{|cccc|}
\hline $\mathrm{E}$ & $\mathrm{O}_{1}$ & $\mathrm{X}_{1}$ & $\mathrm{O}_{2}$ \\
$\mathrm{~K}$ & $\mathrm{O}_{1}$ & $\mathrm{X}_{2}$ & $\mathrm{O}_{2}$ \\
\hline
\end{tabular}

(Sumber: Suharsimi Arikunto)

Variabel bebas dalam penelitian ini adalah pendekatan matematika realistik (PMR) 
sedangkan variabel terikatnya adalah kemampuan pemecahan masalah matematika siswa. Prosedur penelitian terdiri tiga tahap, yaitu tahap persiapan, tahap pelaksanaan dan tahap akhir.

\section{HASIL DAN PEMBAHASAN PENELITIAN}

Berdasarkan penelitian yang telah dilakukan, diperoleh data kemampuan pemecahan masalah matematika siswa dari hasil pretest dan posttest. Kemudian dilakukan uji normalitas dan uji homogenitas data pretest dan posttest pada kelas eksperimen dan kelas kontrol.

Pengujian hipotesis dilakukan dengan menggunakan uji regresi linier sederhana. Sebelumnya terlebih dahulu di-lakukan uji keberatian dan uji linieritas. Hasil perhitungan uji keberatian dapat di-lihat pada tabel berikut :

\begin{tabular}{|l|c|c|c|c|}
\hline \multicolumn{1}{|c|}{ Varians } & DK & JK & RJK & $F_{\text {hitung }}$ \\
\hline Reg (a) & 1 & 153409,09 & - & $F_{\text {hitung }}$ \\
$=17,9$
\end{tabular}

perhitungan keberartian koefisien regresi diperoleh $\mathrm{F}_{\text {tabel }}=4,16$. Dengan demikian dapat dilihat bahwa $F_{\text {hitung }}>F_{\text {tabel }}$ yaitu $17,96>4,16$ maka $\mathrm{H}_{0}$ ditolak. Maka dapat disimpulkan koefisien arah regresi cukup berarti.

Setelah di uji keberatian, selanjutnya dilakukan uji kelinieritasan. Hasil uji kelinieritasan dapat dilihat pada tabel berikut :

\begin{tabular}{|l|c|c|c|c|}
\hline Varians & DK & JK & RJK & $F_{\text {hitung }}$ \\
\hline $\begin{array}{l}\text { Tuna } \\
\text { Cocok }\end{array}$ & 7 & 2105,99 & 799,25 & 3,34 \\
\hline Kekeliruan & 24 & 239,20 & 239,20 & \\
\hline Total & 31 & 2345,19 & 1038,45 & \\
\hline \multicolumn{4}{|l}{} \\
\hline
\end{tabular}

Berdasarkan tabel dan grafik diatas dapat dilihat bahwa $F_{\text {hitung }}<F_{\text {tabel }}$ yaitu 3,34 $<$ 4.26. Maka dapat disimpulkan bahwa $\mathrm{H}_{0}$ diterima sehingga regresi $\mathrm{Y}$ atas $\mathrm{X}$ linier.

Setelah melakukan uji linieritas dan uji keberatian dikedua kelas maka dapat menghitung uji hipotesis pendekatan matematika realistik (PMR) menggunakan rumus korelasi product moment. Hasil perhitungan uji hipotesis dapat dilihat pada tabel berikut :

\begin{tabular}{|c|c|c|c|c|}
\hline Pengaruh & $\mathbf{r}$ & $\begin{array}{c}\mathbf{t}_{\text {hitun }} \\
\mathrm{g}\end{array}$ & $\mathbf{r}^{2}$ & $\begin{array}{c}D \\
=r^{2} \times 100 \%\end{array}$ \\
\hline $\begin{array}{l}\text { Pendekatan } \\
\text { matematika } \\
\text { realistik } \\
\text { (PMR) dan } \\
\text { kemampuan } \\
\text { pemecahan } \\
\text { masalah } \\
\text { matematika }\end{array}$ & 6. & $\begin{array}{l}\text { \& } \\
\text { ஜ̂ }\end{array}$ & 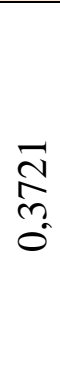 & $37,21 \%$ \\
\hline
\end{tabular}

Dari hasil perhitungan pada tabel diatas, Sehingga dapat dilihat $t_{\text {hitung }}>t_{\text {tabel }}$ yaitu $0,61>$ 0,344. Maka Ho ditolak. Artinya pada taraf signifikan $\propto=0.05$ terdapat hubungan antara pendekatan matematika realistik (PMR) dan kemampuan pemecahan masalah matematika siswa. Nilai 0,61 juga menunjukkan arah hubungan yang positif artinya pengaruh pendekatan matematika realistik (PMR berbanding lurus dengan kemampuan pemecahan masalah matematika.

Dimana besarnya pengaruh pembelajaran pendekatan matematika realistik (PMR terhadap kemampuan pemecahan masalah matematika siswa sebesar $37.21 \%$. Dengan demikian dapat dikatakan bahwa terdapat pengaruh pendekatan matematika realistik (PMR terhadap kemampuan pemecahan masalah matematika siswa.

\section{KESIMPULAN DAN SARAN}

Berdasarkan analisis data dan pembahasan maka diperoleh $r_{\text {tabel }}=0,344$ sementara berdasarkan perhitungan yang telah dilakukan diperoleh $r_{\text {hitung }}=0,61$. Dari perhitungan terlihat bahwa $\mathrm{r}_{\text {hitung }}>\mathrm{r}_{\text {tabel }}(0,61>$ $0,344)$ maka $\mathrm{H}_{0}$ ditolak dan $\mathrm{H}_{\mathrm{a}}$ diterima, dengan demikian dapat disimpulkan bahwa" Terdapat pengaruh pendekatan matematika realistik (PMR) terhadap kemampuan pemecahan masalah matematika siswa kelas X SMA Negeri 2 Binjai tahun pelajaran 2018/2019.

Berdasarkan kesimpulan, maka peneliti menyarankan hal-hal sebagai berikut :

1. Bagi siswa, diharapkan melalui pendekatan matematika realistik dapat membantu siswa meningkatkan kemampuan pemecahan masalah matematika siswa 
khususnya pada pokok bahasan sistem persamaan linear tiga variabel.

2. Bagi guru, sebagai bahan masukan untuk menggunakan pendekatan matematika realistik dalam peningkatan kemampuan pemecahan masalah matematika siswa. Guru dapat menggunakan pendekatan matematika realistik saat mengajarkan materi SPLTV sehingga mempermudah dan membantu siswa dalam memahami dan menguasai pelajaran. Guru juga mampu membuat soal yang menuntut pengerjaan tahap-tahap dalam kemampuan pemecahan masalah, bukan soal yang dapat dijawab langsung tanpa melalui proses indikator kemampuan pemecahan masalah.

3. Bagi peneliti selanjutnya, sebagai tambahan wawasan tentang penggunaan pendekatan matematika realistik dalam menjalankan tugas pengajaran sebagai calon tenaga pengajar di masa mendatang.

4. Bagi pembaca, sebagai bahan informasi yang ingin melakukan penelitian sejenis.

5. Dengan adanya beberapa keterbatasan dalam melaksanakan penelitian ini, maka sebaiknya dilakukan penelitian lebih lanjut yang meneliti tentang pendekatan matematika realistik terhadap kemampuan pemecahan masalah pada pokok bahasan lain untuk mengukur aspek lain.

\section{DAFTAR PUSTAKA}

IEA TIMSS \& PIRLS. 2015. TIMSS 2015 Mathematics Achievement Eighth Grade. International Study Center.

Herman Hujodo. 2005. Pengenbangan Kurikulum Dan Pembelajaran Matematika.(Malang: UM Press).

Suharsimi Arikunto. 2013. Prosedur Penelitian, (Jakarta: Rineka Cipta).

Muchlis, E. E. (2012). Pengaruh Pendekatan Pendidikan Matematika Realistik Indonesia (PMRI) Terhadap Perkembangan Kemampuan Pemecahan Masalah Siswa Kelas II SD Kartika 1.10 Padang (Jurnal Exacta, Vol. X. No. 2) 